\title{
SELECTION AND TRAINING FOR MANAGEMENT IN BRITISH NATIONALIZED INDUSTRIES $\dot{\dagger}$
}

\author{
Reginaid W. BeLL*
}

I

INTRODUCTION

Prominent among the ideas underlying the nationalization of British industries is the conception that, by means of nationalization, the workers in the industry are able to share in its ownership. This doctrine has long been advanced by those who hold that a man working for a private company and having no share in the ownership of that company may be working merely to increase the profits of the shareholders and is in danger of exploitation. The degree to which the worker in a nationalized industry can, as a practical matter, be said to share ownership in it may appear exaggerated, but the doctrine has been successfully preached for so long in Great Britain that it has received wide acceptance among those to whom the socialization of industry has a strong appeal. There is no doubt that for many rank and file and other employees satisfying psychological consequences flow from the initial process of nationalization. At the moment it takes place a proprietary outlook develops, and indeed this feature was the keynote of many humorous cartoons in most sections of the British press for some weeks after nationalization of the railways.

In those activities, e.g., broadcasting, which have been national from the outset, any desire on the part of those who work in the organization to feel a proprietary sense towards it has presumably been met from the beginning. It is, therefore, in relation to industries which have formerly been carried on under private enterprise that the desirability of satisfying the proprietary feeling among the employees has been most strongly urged. In such industries as coal, transport, and steel, advocates of nationalization expected to see conspicuous benefits in this respect from the change.

The owners or proprietors of an undertaking are traditionally considered to be the persons most interested in its efficiency and success. When, therefore, an industry is nationalized and the employees receive some share in the ownership, an added interest in the efficiency of the concern should be conferred upon them. It can

+ Author's Note. The author is indebted to leading officers of the organizations mentioned in part II of this article for the facts on which that part is based. The remainder of the article contains material for which the author alone is responsible, and the views therein expressed must not be taken as representing those of the Administrative Staff College or any organization mentioned in the article.

* LL.M. 1928, University of Liverpool. Of the Inner Temple, Barrister-at-Law. Senior Member of Directing Staff, the Administrative Staff College, Henley-on-Thames. Joint author (with the late Sir Gwilym Gibbon) of HrstoRy of THE London County CounciL, I889-1939 (1939). Member of Council, The Institute of Public Administration. 
also be expected that this interest will take a personal form: each person serving in the industry will wish to play his full part in improving the efficiency of the undertaking and will take every step to further his own knowledge in order to contribute more to the common good. Two things follow: first, that the organization must provide every facility for its employees (of all ranks) to obtain the necessary training and education; and second, that the road to advancement should be the demonstration of ability to assume further responsibility. It is only if this broad conception of the place of the individual in relation to the efficiency of the organization and the opportunity it affords for personal development and promotion is given reasonable reflection in practical arrangements that the proprietary sense, which it is an aim of nationalization to foster among employees, can gain full satisfaction.

It is not surprising, therefore, that, in all Acts of the British Parliament which provide for the taking over by public corporations ${ }^{1}$ of great industries, there is specific provision for the training and advancement of those who are engaged in them. The provisions differ, but the general principle is the same. The corporations are obliged (in one case empowered) to provide training and education, those terms being unqualified, and presumed, therefore, to imply all kinds of training and education, whether technical, administrative, or otherwise, and to relate to all levels of the organization. It is worth while comparing shortly the terms of the various Acts. They are given in date order.

\section{A. Coal Industry Nationalisation Act, 1946}

The National Coal Board is required to carry on activities conducive to advancing the skill of persons employed or to be employed for the purposes of any of its activities, or the efficiency of equipment and methods to be used therefor, including the provision by the Board itself, and its assisting the provision by others, of facilities for training, education, and research. ${ }^{2}$ The Board is further required, in the exercise and performance of its functions as to training, education, and research, to act on lines settled from time to time with the approval of the Minister of Fuel and Power. ${ }^{3}$

\section{B. Transport Act, 1947}

The Transport Commission is given power to do anything for the purpose of advancing the skill of persons employed by the Commission or the efficiency of the equipment of the Commission or of the manner in which that equipment is operated, including the provision by the Commission, and the assistance of the provision by others, of facilities for training, education and research; ${ }^{4}$ and is required, in the exercise and performance of these functions, to act on lines settled

\footnotetext{
1 Throughout this article the phrase "public corporation" is used in the specialized British sense of bodies answerable in some degree to the public at large and set up as national bodies. It is not intended to include either local government bodies or limited liability companies.

${ }^{2}$ Coal Industry Nationalisation Act, 1946, 9 \& 10 Geo. 6, c. 59, §r(2)(f).

${ }^{2}$ Id. $\$ 3(3)$.

Transport Act, 1947, 10 \& II Geo. 6, c. 49, \$2(2)(b).
} 
from time to time with the approval of the Minister of Transport. 5 These powers can be delegated to the Executives set up to assist the Commission, and have in fact been so delegated. ${ }^{6}$

\section{Electricity Act, I947}

The British Electricity Authority and every. Area Board are obliged to make, in consultation with an organization appearing to them to be appropriate, provision for advancing the skill of persons employed by them, and for improving the efficiency of their equipment and the manner in which that equipment is to be used, including provision by them, and the assistance of provision by others, of facilities for training and education. ${ }^{7}$ The British Electricity Authority and the Area Boards in the performance of their functions as to training and education are to act in accordance with a general program settled from time to time in consultation with the Minister of Fuel and Power. ${ }^{8}$

\section{Gas Act, $\mathbf{1} 94^{8}$}

All Area Boards set up under this Act are obliged, in consultation with any organization appearing to them to be appropriate, to make provision for advancing the skill of persons employed by them, including the provision by them, and the assistance of the provision by others, of facilities for training and education. ${ }^{9}$ They are further, if so required by the Gas Council, to submit from time to time to that Council programs showing the provision to be made by them in fulfilment of the obligation set out above; and it is the Council's duty to co-ordinate those programs and settle from time to time, in consultation with the Minister of Fuel and Power, a general program for these matters, to which the Area Boards must give effect. ${ }^{\mathbf{1 0}}$

\section{E. Iron and Steel Act, 1949}

There does not appear to be an express provision in the Act requiring the Iron and Steel Corporation of Great Britain to undertake training and education. Presumably it is one of the powers included in the very wide provisions of Section 2(4) of the Act, ${ }^{11}$ and this inference is confirmed by the terms of Section $4(3)$ of the Act, which provides that, in making or securing provision for the training and education of persons employed by the Corporation or any publicly owned company, the Corporation shall act in accordance with a general program settled from time to time with the approval of the Minister of Supply. Section 3(I)(c) of the Act imposes on the Corporation a positive duty to decentralize.

The most noticeable variation in the provisions above quoted is the progressive

' $1 d^{2} \S_{4}(3)$.

- Id. 55; and Britsh Transport Commission Report par. io (1948).

${ }^{7}$ Electricity Act, I947, to \& II GEo. 6, c. 54, $\$ \$ 2(2)$ and 6(2).

${ }^{8}$ Id. $\$ 5(3)$.

- Gas Act, 1948, II \& 12 Geo. 6, c. $67, \$_{4}(\mathrm{r}) . \quad{ }^{10} I d . \$_{4}(2)$.

${ }^{11}$ Iron and Steel Act, 1949, 12 \& 13 GEo. 6, c. 72, $\$ 2(4)$ reads: "The Corporation shall have power to do any thing ... which in their opinion is calculated to facilitate the proper carrying on of their activities or the proper exercise of their powers under the preceding provisions of this section." 
decentralization of power to perform the functions. This feature reflects the growing experience of the operation of nationalization in Great Britain and the need to avoid the dangers of over-rigidity inherent in very large unitary organizations. No doubt the decentralized provisions of the later Acts will be found to make the planning of training and educational arrangements easier, and, particularly, to facilitate variations to meet local needs. Why, in the case of the Transport Act, only a power is conferred whereas in other cases a duty is imposed, is not easy to explain.

The essence, however, of all the provisions is the presumable intention of Parliament that no one serving in any of these organizations should feel that he is employed by a body within whose service training and advancement for the individual are not given special consideration. There may be good reason to suppose that the inclusion of these provisions was closely linked with the feelings which employees in particular industries were said to entertain before nationalization-feelings of frustration and uncertainty about their future. The absence of such express provisions in some other nationalization Acts has already been commented on. There is no such provision in the Bank of England Act, $1946,{ }^{12}$ possibly because the purposes of the Bank of England have always been so closely associated with service to the nation as a whole that no such feeling as was attributed to employees in other nationalized industries developed in the Bank of England. Again, no such provision was made in, or has since been introduced into, the legislation which governs the Airways Corporations. ${ }^{12}$ Nor, again, do we find provisions of this kind in the Overseas Resources Development Act, $1948 .^{13}$

The only point made here, of course, is the absence of an express requirement. It by no means follows that provision for training and advancement of employees within these last mentioned bodies is not adequately made. The existence of an express power or mandatory duty, however, in the other cases does seem to have resulted in parts of the annual reports of the public corporations concerned being devoted to a description of their training and educational arrangements, and it seems likely that these parts will grow more substantial. In other cases it is not possible to glean from the annual reports what is being done in this matter as a whole: references are chiefly confined to improvement of technical skill in some sections of the staff, e.g., the training of flying and technical ground personnel in the Airways Corporations or the training and development of native employees overseas in the case of the Overseas Food Corporation. It must be admitted that, from the point of view of public enlightenment, express statutory requirement about training and education for employees has a wholesome and stimulating influence.

In this article it is proposed to make particular reference to training for higher management. The higher management of a concern is in a more healthy condition

129 \& ro Geo. 6, c. 27.

122 Air Corporations Act, 1949, 12, I3 \& I4 GEO. 6, c. 91.

${ }^{13}$ II \& 12 GEo. 6, c. I5. This Act set up the Overseas Food Corporation and the Colonial Development Corporation. 
if the arrangements for training and progress at all levels are in good order. For this reason some account is given of provisions made at lower and intermediate levels. A continuous and well-regulated flow of individuals with varied qualifications, from whom the higher ranks of the organization can be recruited, can be ensured only by careful planning. In filling high posts it is wise, and customary in the British public services, to consider the available field of candidates from outside. It follows, therefore, that the methods of training and education used within the organization must be such as to secure that those who come up internally with claims for appointment to high-level posts shall have had at least as good past opportunities to equip themselves as are available to outsiders against whose competition they must stand. This calls for a deliberate policy of suitable internal transfers to widen the experience of the individual. In the interests of a contented and therefore efficient staff, the process cannot start too early, and a scheme whereby promising individuals are, from an early stage in their career, given an opportunity of finding their way up the ladder is specially important in very large organizations where the numbers and extent of the staff may otherwise create blocks of individuals for whom outlets by way of promotion are inadequate. It is a corollary, too, of such a scheme that the organization should contemplate at different stages some loss of promising individuals through their gaining employment elsewhere. In the case of monopolistic bodies such as a nationalized coal industry, however, the departure of members to posts in other organizations is likely to be far more common on the administrative than on the technical side, as clearly men of high technical ability in coal mining are not normally likely to seek, or gain, employment in some entirely different industry.

Having said so much by way of general introduction to the subject, it may be best now to make some comparisons between what is done in one of the earlier public corporations, not under any special statutory requirement about staff training, and what is being undertaken by two of the large post-war public corporations which have been placed by act of Parliament under a specific responsibility in this matter. In an article of this length it is hardly feasible to record in detail the arrangements made by all the bodies concerned. Moreover, such arrangements take much time and thought to develop, and the more recently created public corporations have not yet had time to complete and put into effect a full range of training and education schemes. Among the post-war public corporations, therefore, the two of longest standing have been chosen.

It also has to be remembered that, for this very reason, many of the arrangements made by the newer nationalized bodies are still in the planning stage. They are being built on practical foundations laid before nationalization took place, and due credit should be given to those who laid those foundations. 
II

\section{Descriptron of Selected Schemes}

\section{A. The British Broadcasting Corporation}

The British Broadcasting Corporation is a body constituted by Royal Charter and operating under licence from the Postmaster-General. Although it is the practice of the British Broadcasting Corporation to fill its higher posts as the result of advertisement both inside and outside its own service, there is no specific requirement for the Corporation to do so nor any obligation to make arrangements for training employees. Apart from those fields of the work of the Corporation which give special outlet for engineers, more particularly electrical engineers, the higher posts are regarded by the Corporation as calling for a blend of administrative and technical ability. The British Broadcasting Corporation is no part of the Civil Service, nor is the nature of its work truly comparable. The Corporation has never adopted the long-standing convention of the British Civil Service under which a definitely preponderant position is given to the administrative officer, who is charged with formulating and executing policy, all technical officers being regarded as advisory to those who hold the administrative positions. The higher officers of the British Broadcasting Corporation are not administrators aided by technical advisers, but carry out a blended function. There are few purely administrative positions anywhere in the Corporation's service, and, at the higher level, few purely technical posts. The upper ranges of this organization call for a faculty which might perhaps be described as administrative ability combined with technical knowledge, and for the generality of higher posts it is this blended capacity which the Corporation needs.

In one respect, however, a civil service precedent has been followed. The British Broadcasting Corporation strongly believes in the value of practical experience as a process of training. Just, therefore, as it is regarded as part of the duty of the senior civil servant to make sure that his juniors are trained for promotion, so do the higher officers of the British Broadcasting Corporation look upon it as part of their task to ensure that those under them are trained for future higher responsibilities. This type of grooming for the future cannot, of course, be readily described, as it is by no means formalized. Its reality and effectiveness depend upon the operation of a deliberate internal policy of moving promising individuals from post to post at suitable intervals, so that the range of their experience is widened and their training progressive. A scheme for achieving this is being worked out, and when in operation should help to secure that flexibility of attitude towards administrative and technical faculties which is necessary for those who are called on to perform the blended functions already described.

It has not been thought necessary by the Corporation to provide any training college of its own, or any internal staff college. There is, however, an internal school to which are sent officers of medium levels recently recruited from outside, 
mainly to give them a month's introductory course to the service of the Corporation as soon as conveniently possible after joining. In addition to furnishing a specialized introduction in this way, the course also provides a useful mixing ground for newcomers and those of long standing in the service. Numbers of the latter attend it as a refresher course, and members are drawn also from the ranks of overseas broadcasting services in many lands. For the technical side there is an internal engineering training school, which gives three-month training courses in preparation for promotion examinations, and also refresher courses for technicians.

These courses, however, are in no sense management training courses, and, indeed, the Corporation does not carry out any deliberate management training as such. It is arguable whether the practical administrative training referred to earlier is as good a form of management training as can be devised, but the Corporation has every intention of using external facilities, including any that may be developed under the aegis of the British Institute of Management. It may well be that the British Broadcasting Corporation will find it valuable to make growing use of the conference method, in such forms as the holding of summer schools, which it has not yet tried.

In short, the position is much what one would expect to find in an organization which has grown steadily from a sudden start and is devoted to a single purpose. There are no problems here of reconciling former competing policies, or attempting to unify divergent practices whose differences are rooted deeply in past traditions. The problem is rather the converse one-namely, how, when new branches grow out of the original tree and bear fruit, can they be held together by bonds which will ensure the unity of the Corporation as a whole without hindering progressive development. The reality of this problem was conspicuously illustrated recently in the case of the television service and the strong expressions of view to which the question of its future mode of development gave rise.

\section{B. The National Coal Board}

If we take as our next example the National Coal Board, we find ourselves examining the earliest case where a statutory duty to train employees was placed on a nationalized body. Here, a very different problem has demanded an appropriately different solution. On the nationalization of the coal industry, the Coal Board found itself the heir to a very large number of private companies greatly differing in size, and many of them having an exceptional range of ancillary activities. Although valuable work had been done by the Mining Association of Great Britain on the technical side of the industry, there was no central staff plan nor conception within the industry of membership of a single service. Moreover, recruitment to the coal mining industry at all levels was patchy, and for anyone contemplating a career in it the course of promotion was problematical.

To meet the first need for a flow of promising recruits to the medium levels of 
the industry, the Coal -Board has produced a scheme to which it has given the name of "The Ladder Plan." The essence of this scheme is that, for all new entrants to the industry undergoing preliminary training, there should be available a definite ladder of promotion to higher ranks; and, further, that, as the individual progresses upwards, the available ladders should increase in number as they diminish in width, so that the best use of varying talents can be made. Present juvenile recruitment to the coal industry runs at the rate of about fifteen thousand a year, and the ladder plan provides that about 20 per cent of each year's entrants get onto the main ladder right away.

Progress up the training ladders will lead to the acquisition of various certificates -the General Certificate leading either, on the one hand, to qualification as a certified tradesman or as the holder of a Statutory Certificate eligible for employment as a deputy; or, on the other, through the acquisition successively of the Ordinary National Certificate and the Higher National Certificate, to eligibility for employment as undermanager, mechanical or electrical technician, or surveyor. In speaking of the scheme at the beginning of 1950, Sir Geoffrey Vickers, V. C., the Manpower and Welfare Member of the National Coal Board, said:

These certificates will not by themselves constitute a qualification for any job in the pit. They will supply only the formal part of the qualifications. Those who are to be tradesmen will have to complete a five years' apprenticeship, taking a General or Ordinary National Certificate before being qualified in any skilled job in their trade at the pit. Men selected for training as deputies must have practical experience and must undergo practical and oral tests whether they have a certificate or not, though those who have a certificate will be entitled to practice as deputies, and subsequently as overmen, earlier than they otherwise would.... The importance of the scheme lies in ensuring that men who have it in them to fill responsible posts may not be held back later through having failed to pursue their general and technical education sufficiently in their first years after leaving school.

The value of a scheme of this scale and variety in giving effect to the aspirations which, as mentioned at the outset of this article, were encouraged by nationalization, needs no emphasis. The Board records ${ }^{14}$ that in preparing this scheme it drew on much work done in the past by the Mining Association of Great Britain and other bodies, and that the plan brings together the projects and ideas of many people over many years. The scheme is, indeed, the foundation-stone upon which the National Coal Board seeks to fulfill its basic promotion policy for its technical staff on the production side.

It is the Board's policy to fill most of the senior posts on their staff from among people already employed in the industry. In future many of those who achieve promotion to the higher ranks will have entered the collieries as mineworkers, and by means of the courses of study and experience provided under the Ladder Plan will have joined the ranks of management. Others will be men and women who have been recruited into

${ }^{14}$ National Coal BonRd Report par. 289 (1949). 
clerical, administrative or specialist posts straight from school or from the University. Whatever their educational origins, all will have opportunities for learning their job thoroughly and, as time goes on, of broadening their experience. In this way the best will be able to fit themselves for promotion. ${ }^{15}$

When we come to the level of colliery manager, the Board has instituted important training arrangements.

All colliery managers have to take a statutory qualification for which a university degree or the Institution of Mining Engineers' professional examination may in future be accepted partly or wholly in substitution. In addition, they will receive three years' directed practical training in accordance with a syllabus prepared by the Institution. The men who enter on this training may be men from within the coal industry who have taken or are about to take the appropriate examination by part-time study. For these the higher National Certificate is expected to be of substantial assistance. Equally they may be men from within the industry who have graduated in mining through a whole-time degree course. Finally they may be mining graduates who have not previously worked in the Industry. To stimulate the flow of mining graduates both from within and outside the industry, the Board in 1948 and again in 1949 awarded roo scholarships, tenable at any University, and it has decided to award a similar number of scholarships for $1950 .{ }^{16}$

The scholarship and directed practical training schemes to which reference is made above are a novel experiment within an industry. The training will last for the individual up to three or four years, depending on previous experience, and is supervised by senior members of the National Coal Board's staff in the coal fields. Among other things it provides for sending prospective colliery managers to residential courses of a fortnight's duration, at which they study their future responsibilities. At the earliest of these residential courses, which were held in the Mining Departments of six Universities, the syllabus was arranged under three main heads:

(I) The status, duties, and responsibilities of a colliery manager;

(2) The place of the colliery manager in the organization of the $\mathrm{Na}$ tional Coal Board;

(3) The relation of the colliery manager to the labor force.

The study took the form of group discussions, organized on the basis of "briefs" in which problems were set out, and persons of wide practical experience in the subject attended the courses in order to guide the discussions and give lectures based on their own knowledge.

Under the first heading mentioned above the prospective colliery manager studied all the duties and responsibilities that would fall to him within the colliery under his own control, and emphasis was laid on the standing which he must keep in the eyes and minds of all working in that colliery. Under the second heading he was invited to look outwards and to survey and understand the wider organization of the National Coal Board and the responsibilities which he would bear both to the higher levels of the Board at Area, Division, and Headquarters, and laterally to other 
parts of the organization with which he must be linked for various purposes. It was under this head, too, that the students particularly studied their relationship to technical specialists and others whose assistance and advice would be available to them in their task. Under the third heading was conducted what amounted to a specialized study of the handling of trade union relationships and the process of joint consultation.

This directed practical training has been too recently instituted to assess results, but there is no doubt that, apart from any other benefits, it will be specially valuable in enabling the colliery managers of the future to rub shoulders with each other, instead of attempting to develop quite separately as individuals. It will have, too, a secondary advantage to the Board in fostering a sense of membership in a united service. The training is available every year to two hundred men selected by the Divisional Boards.

The Coal Board has already held four very successful summer schools, at each of which some four hundred or more attended from all grades in the service of the Board, including mineworkers. At these schools a most useful mixing of the different levels of employees takes place, and the summer schools play as important a part in ensuring vertical contact as do the other arrangements in providing it laterally.

It is only right to record, however, that the National Coal Board regards these schemes only as the first important steps to meet training needs on the productive side of the industry. They are by no means comprehensive, as they do not provide for the whole range of the Board's employees.

\section{The British Transport Commission}

As has already been mentioned, the British Transport Commission has delegated the duties of training and education laid upon it by the Transport Act, 1947, to the Executives set up under the Commission, namely, the Railway Executive, the London Transport Executive, the Docks and Inland Waterways Executive, the Hotels Executive, the Road Haulage Executive, and the Road Passenger Executive. The Commission retains, however, coordinative power and, indeed, is bound to submit to the Minister of Transport a program on which the Executives are to work. In its first annual report the Commission was able to declare that it had made a survey of the existing training and educational facilities of the Executives and, as a result, had formulated proposals to widen and improve them. These proposals were designed to secure the following objectives as circumstances might permit:

(I) To equip staff as quickly, as thoroughly, and as economically as possible to perform their tasks with the maximum of efficiency and safety and personal satisfaction in their calling;

(2) To interest staff in their work, and give them a sense of pride in the job to be done, without which technical proficiency loses much of its value; 
(3) To interest staff in the work and aims of the organization as a whole, and by fostering their "sense of belonging" enlist their interest in the success of the undertaking;

(4) To maintain efficiency, alertness, and interest in the work by providing refresher courses in up-to-date ideas, methods, and developments;

(5) To provide opportunity to acquire the necessary knowledge and skill for promotion;

(6) To provide trained staff from whom higher posts can be filled.

The proposals were thus intended by the Commission to provide for vocational training, background training, voluntary training, and further education. ${ }^{17}$

The Commission has also established a Standing Training and Education Committee, comprising members and officers of the Commission and the Executives, to advise on major problems concerning training and education. The purpose of this companies, inherited a more coherent situation than the non-railway Executives (other than the London transport Executive).

In the following year the Commission was able to report that the program for staff training and education, drawn up on the above lines, had been approved by the Minister of Transport, who had given authority to the Commission to proceed. Since then the Executives have been preparing their schemes under the program in close cooperation with each other and with the Ministry of Education in England and Wales and the Scottish Education Department in Scotland. They have also kept in close touch with local education authorities through directors of education.

These schemes are, of course, in the early stages, and it would be premature to attempt a detailed description. It may, however, be well to give some account of the position of the Railway Executive who, by reason of antecedent events, in that the railways had already been grouped some years before nationalization into four large companies, inherited a more coherent situation than the non-railway Executives. (other than the London Transport Executive).

Within the activities covered by the Railway Executive special problems had to be faced at the outset. The Executive took over four large companies created under the Railway Act of rg2I, namely, the Great Western; London, Midland and Scottish; London and North-Eastern; and Southern Railways. There was no very marked divergence between the general staff policies pursued in each of these large units, but there were strong traditions in each of them which went back before I92I to the days of the original railway companies. The railway system of Great Britain has always been haunted by the ghost of George Hudson, M.P., the nineteenth century "Railway King" whose lavish promotion of railway lines, especially in the midlands, set so many problems for posterity. The nature and amount of railway equipment make the physical side of the railways a fact which legislation cannot

17 British Transport Commisston Report par. 57 (1948). 
suddenly change. The railways must be administered as they are, however strong the desire to unify the system may be. All schemes, therefore, for the organization and day-to-day running of British railways are conditioned and limited by the physical layout and operational peculiarities of the lines.

Before the Transport Act, 1947, there was little movement of staff between one railway group and another. Today, up to the salary level of $£ 75^{\circ}$ a year, it remains the normal practice to advertise posts only within each railway region. These regions are the London Midland, Southern, Western, Eastern, North-Eastern, and Scottish Regions. Above the salary level of $£ 75^{\circ}$ a year vacancies are advertised in all regions. The actual power to make the appointment rests, below the $£ 750$ a year salary level, with the Chief Regional Officer of the region concerned; above

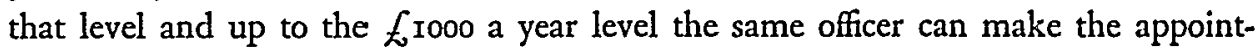
ment with the approval of the Railway Executive. Numerous transfers between regions result in this upper level from these circumstances, though there are signs, perhaps not unnaturally, that Chief Regional Officers, when other things are equal, prefer to appoint to a vacancy a man from their own region of origin, trained in the tradition with which they are familiar.

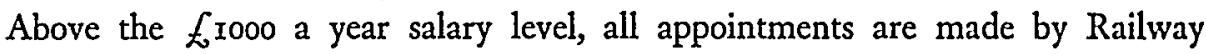
Executive headquarters, a board being suitably composed, according to the nature of the appointment, of chief officers from headquarters and the region concerned. In case of disagreement the decision is by a majority of the board.

The Railway Executive was fortunate in finding that, in general, the policies of the groups which it took over had not given rise to any notable mal-distribution of age groups, and difficulties arising from blocks of individuals with inadequate outlets for promotion are not found to be unduly hard to solve.

One of the hopes of some advocates of nationalization has always been the reduction of staff and saving of manpower which could be brought about by unifying services and amalgamating duties so that overlapping would be avoided. The possibilities of savings of this kind on the operational side of the railways have been slight. The working of trains being a through operation, little can be done by mere amalgamation of posts to make savings of staff, and some types of apparent duplication of officials cannot be avoided. For example, Birmingham is served by the lines of the old Great Western Railway, London and North-Western Railway, and Midland Railway, and there were, and still are, three railway superintendents overseeing the operation of these distinct sections. What appears here to be a mere duplication of effort is, in fact, the coincidence at the same place of three operational units engaged on different tasks. The physical methods of working these old lines differed-for example, Great Western locomotives have always been right-hand driven, London and North-Western and Midland locomotives were some right-hand and some left-hand driven, and the later London, Midland and Scottish locomotives are all left-hand driven; signals and other apparatus vary accordingly, and even the 
systems of logging trains on the three lines are quite distinct. For such circumstances the only present solution is to continue to operate the three units as before, and this is further justified by the fact that, in any event, the volume of work involved would require the three superintendents and their staffs, however the duties were re-arranged. It is, of course, the aim of the Railway Executive to unify the railway system of the country in time, but it needs no emphasis that any project of that kind can only be carried out slowly over a very long period.

On the commercial side of railways, on the other hand, it has been found possible to do a great deal of amalgamation of posts, and the Railway Executive has had to face the problem of staff rendered redundant by these reorganizations. Here again, the transfer of individuals from one region to another is obviously much easier, and the opportunities for unifying procedures far greater. Greater flexibility, too, can be incorporated in staff transfer and training arrangements.

Within the Railway Executive there is no "Ladder Plan" comparable to that of the National Coal Board, but the long-established railway apprentice scheme provides opportunity for advancement to talented young men in the service. Before nationalization some of the main line railway companies had set up internal staff colleges, that established by the London Midland and Scottish company at Derby being a prominent example. The future use of these colleges and the possibility of their expanding to serve wider needs is now under examination. The present concentration by the Executive is on the production of an adequate supply of teachers, and two residential training colleges at Darlington have been combined for training in teaching method. The resultant supply of teachers will be the foundation of the Executive's educational program.

The foregoing description is confined to the internal arrangements of the three public corporations. There is, however, an external facility for higher management training of which mention should be made.

\section{The Administrative Staff College}

For training members of their staff who show promise of attaining very high positions in the undertakings, many of the British nationalized industries make use of the Administrative Staff College at Henley-on-Thames. The College is the only institution of its kind and draws its members from all over Great Britain, and some from overseas. It was established and is maintained entirely by British private enterprise. In addition to nominees from other quarters described later, courses at the College are attended by nominees from the British Broadcasting Corporation, the National Coal Board, the British Electricity Authority, the Colonial Development Corporation, the Bank of England, and the following Executives and Authority of the British Transport Commission-the Railway Executive, the London Transport Executive, the Road Haulage Executive, the Docks and Inland Waterways Executive, and the Ulster Transport Authority. The aim of the College is to aid the de- 
velopment of administrative skill at the highest level. Three times a year it brings together some sixty men and women who are already experienced administrators and hold responsible positions in quite different walks of life. When they have been assembled under the College roof, where they dwell together for about twelve weeks, they find that a framework is provided for them which is designed to give opportunity to develop their own ideas. There are two parts to this framework-the general environment of the College and the course of studies itself-and the two are complementary.

The College, which is at Greenlands, a large country house on the banks of the Thames near Henley, has been adapted to enable work to be done in circumstances as free as possible from distracting influences. There are enough means of recreation round about to give adequate relief from the intensive course, the house stands by itself in pleasant widespread grounds, and the corporate spirit necessary for the success of the College method grows naturally in this environment.

The program of studies is designed for mature men and women, and is not a teaching course in any sense. The College has no doctrine to preach, and there is little teaching by lectures. The real aim is to give progressive direction to the discussions on which members arriving at the College are anxious to embark among themselves, and to enable them not only to interchange their own ideas but to be assisted in the process by having readily to hand additional means of information through books, visitors, and visits paid to outside institutions.

The course is, however, much more than a mere series of discussions. An important underlying object is to give members the opportunity of practising, without important consequences hanging upon the results, some of the things in which an administrator at the highest level requires to be particularly skilled-such matters as handling a group of collaborators as distinct from giving orders to a group of subordinates; enabling such a group to reach conclusions on controversial subjects within a limited time; handling expert advisers in such a way that they provide the advice and information that the group requires as distinct from any particular "line" that they themselves have to offer; mastering the raw material which has to be handled before sound conclusions can be reached, whether that material be obtained from documentary or human sources; and putting forward, on behalf of and in the presence of others, in conference or before more formal audiences, views resulting from group discussion.

Perhaps the most important part of the work is done in the syndicates of nine or ten into which the members of the College are divided. Each syndicate is composed of men and women whose backgrounds differ as much as possible from each other, so that the purpose of mixing experiences may be achieved. Changes of syndicate are made, of course, for some subjects, in order to give opportunities to members for working with fresh groups.

This is not perhaps the occasion to detail the subjects which are dealt with in 
the College course. It may suffice to say that they are designed to throw up as many as possible of the major problems faced by administrators at a high level in any kind of organization, and, in particular, to give the members the opportunity to use their own experience in attempting to find solutions to such problems, as distinct from having to rely on written material or secondhand evidence, as is necessary where the normal "case method" is employed.

The essence of the Administrative Staff College is to provide a mixing ground for men and women drawn from the higher levels of a wide variety of organizations. Those who are sent by the nationalized industries find themselves associated with nominees, at their own level of responsibility, from both large and small firms engaged in private industry and commerce of all kinds, banking, accountancy and finance, insurance, the civil service, local government, and the fighting services. 'The only important section of industrial life not yet represented at the College is the trade unions, but it has been from the outset the policy of the College to welcome them in every session-and, indeed, its work must be to some extent imperfect until trade union nominees join in the College courses.

\section{III}

\section{Some General Observatrons}

In view of the hope that has always been expressed by advocates of nationalization that the process will lead to more efficient conduct of the industries so treated, there is natural concern about the general efficiency of these great new organizations. It is assumed to be a principal objective of requiring public corporations to establish promotion and training schemes that thereby their full efficiency can be fostered. The modern doctrine that efficiency cannot be achieved unless those employed have a sense of satisfaction in their work is now widely accepted. Opportunities for improvement of personal skill and for progress to higher levels of responsibility, which training schemes ought to assure, will more than any other one factor bring about this sense of satisfaction.

On the other hand, one must make full allowance for the difficulties that beset any attempt to bring quickly into being every ramification of such very large undertakings. Although the organizations themselves may be formally set up, it is physically impossible to bring about hastily the complex changes which affect the thousands of employees and need time to mature. The interval since even the longest-established of the post-war public corporations was set up in Great Britain is so short that it is not yet possible to do more than outline some of the promotion and training arrangements so far partially made and the hopes that are entertained for the future. Time is an ingredient in successful organization, and it is far too early to claim results from what has been put in hand up to this stage.

A further matter on which it is too early yet to see any advance is the problem of coordination between the training schemes of the various nationalized industries. 
It is obviously desirable that there should be some coherence of plan. This rests at present on such liaison as may be maintained between one nationalized industry and another and on the valuable part which is played by the Ministry of Education and the Scottish Education Department, who are consulted by the nationalized industries about their schemes and can discuss them with knowledge of what is happening in other directions.

One of the subjects of training for management is to produce men and women who are efficient in encouraging and controlling the work of others and are familiar with, and able to use competently, modern management techniques. Training schemes should, of course, cover these matters adequately, and seek to develop in trainees the capacity to conduct day-to-day affairs ably and readily and to delegate with confidence a sufficiently wide range of duties to those under them. But training, or at any rate higher training, has to go a long way beyond that. Those who are likely to rise to a high level need to be guided to think about the big problems that face the topmost authorities of very large concerns-those in particular that partake of the character of national institutions. The higher up in a large organization a man or woman is serving, the more common ground there is between the problems he or she is facing and those faced by others at comparable level in other big organizations; and the more do certain large national issues, which affect in common all such organizations, take up the time and thought of those who are directing them. Because all nationalized industries are of necessity on a big scale, any training arrangements they adopt should anticipate these needs and develop the capacity required.

Problems of the kind referred to are not far to seek. In Great Britain, the diminishing number of the population in the working age-groups presents a manpower situation in the solution of which the nationalized industries, with their great numbers of employees, must perforce play an outstanding part. In the nationalized industries, again, is to be found the best laboratory in the country for studying the organizational problems peculiar to large-scale undertakings. Further, the method by which these public corporations are to be kept effectively accountable to Parliament and the public remains to be fully worked out and generally understood. Yet again, the means by which such extensive organizations can maintain their own internal vitality and the sense of liveliness and individual vigor in all their employees demands much study. Moreover, in those undertakings which under a national public corporation attain a position of monopoly, the right balance between attempts to coordinate every activity on the one hand, and the deliberate fostering of internal competition and rivalry on the other, has yet to be achieved.

Important as these problems are, and necessary as it is that higher training schemes should have them in mind, there is one problem on which nationalization as a process ought to shed more light than on any other, and that is the possibility of reconciliation between the two so-called "sides" of industry, the managerial side 
and the side represented by the trade unions. It is this objective which is often described as "the achievement of a sense of common purpose." This is a problem distinct from "labor relations," on which there is a separate article in this series. It really amounts to the question whether there shall continue to be, emotionally, two sides of industry, or whether there is some way by which the world of trade unionism can be reconciled, and even in some degree identified, with the management process.

As with so many great problems the real struggle occurs not only in the relationship between organizations but within the individual himself. For example, before the nationalization of the British coal industry, colliery managers were wholeheartedly identified in their own minds, as well as in those of their subordinates, with the managerial "side" of the industry. Since nationalization they remain so, but at the same time have become a part of the great human structure serving under the National Coal Board, and in the Colliery Managers' Association they have a trade union of their own which negotiates to protect their interests in respect of terms of employment. The individual colliery manager, therefore, has now to reconcile his outlook as part of the managerial side in the ordinary conduct of his work with what may be essentially a trade union attitude to his higher employers. This practical difficulty has, of course, faced others in other walks of life, for example, foremen in industry and officials at the intermediate levels in the civil service and in local government. No complete solution to the personal division of allegiance which arises in the man has yet been found, and probably none will be found so long as there is no reconciliation between the forces to which the warring allegiances are owed.

The core of the difficulty may well lie in the fact that when a man, hitherto a member of a trade union, passes on promotion into a higher level, beyond the sphere in which the trade union culls its members, he ceases, in the eyes of his former associates, to be a "union man" and enters a class where his outlook is regarded as irreconcilable with that of a trade unionist. He has passed, as it were, into a hostile camp, to be numbered in future among those from whom attacks on the hard-won rights of trade unions are to be expected. It is remarkable that trade unions in Great Britain appear not to have yet realized the strength of their own position. As Professor G. D. H. Cole puts it:

Trade unionists, on their side, must learn to be less on the defensive and to have greater faith in the impregnability of their Unions, so as not to be constantly in fear of having their trade union loyalties insidiously undermined by collaboration with the management in pursuit of a common task. ${ }^{18}$

The attempt (if it be one) to provide for trade union participation in the management process by including at the top, in the membership of the public corporations

\footnotetext{
${ }^{18}$ Cole, Labor and Staff Problems Under Nationalisation, 21 PoL. Q. 160, 169 (1950).
} 
themselves, trade union men appointed as such, is inadequate. Such a proceeding does no more to effect reconciliation between the managerial and trade union points of view within the organization than putting a military cap on a civilian's head would do to turn him into a soldier. The problem arises from an attitude of mind, and as training schemes of any kind operate chiefly on the minds of those who partake in them they can do much to expedite a solution.

Human prejudices and traditional feelings are, however, so strong that a long time is bound to elapse before an obstacle of this sort can be successfully surmounted. The important thing at present is for its existence to be recognized and for sincere efforts to be made on both sides in an atmosphere of mutual confidence to make progress towards overcoming it. No doubt great benefits would flow if the trade unions wholeheartedly looked on management as the natural outlet and development for the trade unionist. There seems to be no good reason why a trade union should not look upon its members as growing up through, and flowering in, the higher levels of management rather than, as it often seems to do, regarding its most promising buds as cut off when they grow above the level of ordinary union membership. Why should it not be possible for a man, on promotion above the trade union ranks, to be still regarded as keeping his union background? In the respect in which it most matters-the make-up of his character as an individual-the background stays with him all his life. The notion that holding a different position in the organization fundamentally changes his outlook overnight is contrary to human nature. A professional man does not lose his professional grounding by taking a non-professional post: is it, therefore, too farfetched to suggest that trade union experince should be treated as a background qualification just as engineering or accountancy is treated as a background qualification? If this came about, the man going up into the managerial level with a trade union background would be considered as keeping that background throughout his career. Promotion from lower levels within the organization would become the natural means of imbuing management with a proper sense of the trade union point of view. A reconciliation could be thus effected between what have hitherto been described as two sides in industry, without the controversy involved in claims for workers' control. It is a corollary, of course, that on the managerial side a trade union background should be looked on as an asset just as useful in its way as any other, and that the positive desirability of including a proper proportion of persons with that background in managerial ranks should be recognized and fulfilled.

If there is anything in such a hope as this, it is an especially valuable feature of the arrangements made for drawing up training schemes in British nationalized industries that the trade unions are being consulted at every step on the way. The training schemes are the door which should open upon a fair and dispassionate study of this great problem and the development of its solution. It is in the nationalized 
industries above all that the experiment would be most hopefully tried, and a precedent there established might in due time be successfully imported into private industry.

If the training schemes of nationalized industries can in due course give a lead toward the solution even of one or two of the major problems mentioned in these concluding observations, they will confer benefits far beyond the confines of those industries themselves. No better justification could be sought for the inclusion by the British Parliament in nationalization Acts of express and general requirements for training and education. 